\title{
(E)-1-(3,4-Dimethoxyphenyl)-2-methyl-3-phenylprop-2-en-1-one: A P-Type Acid-Stable Photochromic $\alpha$-Methylchalcone
}

\author{
Banu Öngel, Jörg M. Neudörfl and Axel G. Griesbeck *(D) \\ Department of Chemistry, Faculty of Natural Sciences and Mathematics, University of Cologne, Greinstr. 4-6, \\ 50939 Köln, Germany; banu.oengel@gmail.com (B.Ö.); aco48@uni-koeln.de (J.M.N.) \\ * Correspondence: griesbeck@uni-koeln.de
}

check for updates

Citation: Öngel, B.; Neudörfl, J.M.; Griesbeck, A.G. (E)-1-(3,4-

Dimethoxyphenyl)-2-methyl-3-

phenylprop-2-en-1-one: A P-Type

Acid-Stable Photochromic

$\alpha$-Methylchalcone. Molbank 2021,

2021, M1226. https://doi.org/

10.3390/M1226

Academic Editor: Nicholas

E. Leadbeater

Received: 5 May 2021

Accepted: 1 June 2021

Published: 4 June 2021

Publisher's Note: MDPI stays neutral with regard to jurisdictional claims in published maps and institutional affiliations.

Copyright: (c) 2021 by the authors. Licensee MDPI, Basel, Switzerland. This article is an open access article distributed under the terms and conditions of the Creative Commons Attribution (CC BY) license (https:// creativecommons.org/licenses/by/ $4.0 /)$.

\begin{abstract}
The $\alpha$-methylated chalcone 3 with an electron-donor substituted A-aryl ring and an unsubstituted B-phenyl ring was synthesized by base-catalyzed aldehyde/acetophenone condensation. Compound 3 can be photo-switched from $\mathrm{E} \rightarrow \mathrm{Z}$ by irradiation with long-wavelength light $\lambda>350 \mathrm{~nm}$, whereas irradiation with shorter wavelengths leads to photo-stationary states (PSS) with lower amounts of the Z-isomer. The limiting wavelength for fully equilibrated $\mathrm{E} \leftrightarrows \mathrm{Z}(\mathrm{PSS}=1)$ can be achieved around $240 \mathrm{~nm}$. The stability of both E- and Z-isomers at the wavelength-dependent PSS under UV-irradiation between 250 and $350 \mathrm{~nm}$ is remarkably high as observed from UV and NMR spectroscopy. Compound 3 is fatigue resistant even after more than 10 days continuous irradiation and is also oxygenation-stable under singlet oxygen sensitization conditions. In remarkable contrast to many other $\alpha$-methylated chalcones, no change in the E/Z-ratio was detected when PSS samples were treated with Broensted acids. The negative photochromic $E \rightarrow Z$ switch of 3 is accompanied by a conformational switch from the E-form in its preferred s-trans conformation to the Z-form in a distorted s-cis conformation $\left(\mathrm{E}_{\mathrm{s}-\mathrm{c}} \rightarrow \mathrm{Z}_{\mathrm{s}-\mathrm{t}}\right)$.
\end{abstract}

Keywords: photochromism; chalcones; quantum yields; photo-switch

\section{Introduction}

Photochromic molecules have a long tradition in history of chemistry [1]. Initially only an optical curiosity, photochromism developed into a highly productive and technically applicable phenomenon [2]. Compounds that behave photochromically are currently used in very different fields of applications ranging from photo-pharmacology [3-5], signaling, and sensing to information storage materials [6-9]. The general concept is the light-induced unimolecular switch of a molecule to a thermodynamically less stable configurational or constitutional isomer that is coupled with a back reaction that can be also light-induced or purely thermal [7]. Variations that are more complex in applications involve bimolecular processes, such as the addition or release of singlet oxygen [8]. Possible mechanisms for the return process to the initial states beside photochemical (P-type) and thermal (T-type) are Lewis- or Broensted-acid catalysis or changes in solvent properties, ion strength, or other physical parameters $[9,10]$. The structurally most versatile processes are cis/trans $(\mathrm{E} / \mathrm{Z})$ photo-switches that can involve CC-, CN-, or NN-double bonds as central switching units (alkenes, imines, azo compounds) [11,12]. A typical example for a P-type E $\leftrightarrows$ Z-switch with biological relevance is shown in Scheme 1 [13]: E-chalcone 1 shows antitumor-activities that are largely increased in the Z-configuration. A strong increase in pharmacological properties was also described for the electronic ground states of $\alpha$-methylated chalcones in comparison with the non-methylated analogs [14]. We became therefore interested in photoswitch properties of these $\alpha$-methylated chalcones [15] and their stability against singlet oxygen, a reactive oxygen species that often increases system fatigue in the photo-switching processes [16]. 


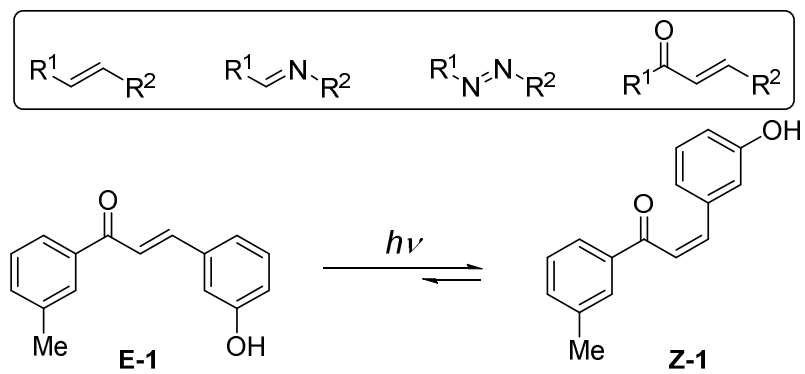

Scheme 1. The four relevant E/Z-photo-switch chromophores and a photochromic chalcone $\mathbf{1}$ with configurationally dependent biological activities: an example for photo-pharmacology.

The target molecule 3 that is described here in detail has a special feature: two electronically highly differentiated aryl groups that were initially expected to lead to red-shifted absorption and higher PSS because of better spectral separation of the two configurational isomers. We have recently determined PSS for different donor-substituted and donor, acceptor-substituted $\alpha$-methylated chalcones [16] and found relatively high Z/E-PSS (60:40 to 76:25) for all compounds using $350 \mathrm{~nm}$ excitation. From these wavelengthdependent PSS switching back to the E-configuration could be realized by treatment with Broensted acids.

\section{Results}

\subsection{Synthesis and Structure of the $\alpha$-Methyl Chalcone 2}

The synthesis of $\mathbf{3}$ is conducted by a classical aldol condensation route in moderate yields (Scheme 2). The reaction proceeds exceedingly slowly (average reaction time at room temperature several days) possibly due to the lower acidity of the $\alpha-\mathrm{CH}$ component. The condensation following aldol addition is highly diastereoselective and the E-isomer is formed with $95 \%$ diastereoselectivity ( $>99 \%$ after one recrystallization).<smiles>CCC(=O)c1ccc(OC)c(OC)c1</smiles>

2

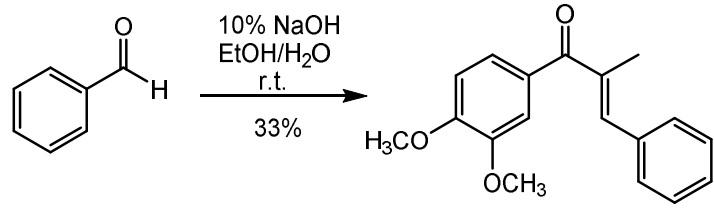

E-3

Scheme 2. Aldol condensation route to diastereoisomerically pure chalcone E-3.

From the NMR analyses, the preferred conformation of E-3 could be estimated: the decisive ${ }^{1} \mathrm{H}$ chemical shift of the $\mathrm{B}-\mathrm{H}$ of $7.1 \mathrm{ppm}$ is indicatively shifted to lower fields in comparison with the $\mathrm{B}-\mathrm{H}$ in the parent E-chalcone (E-4, $7.8 \mathrm{ppm}$, Scheme 3). This interpretation is also supported by the crystal structure analysis of $\mathbf{3}$ (Figure 1). We have recently determined by DFT computations that the E-isomers of $\alpha$-methyl chalcones are preferentially in s-trans configuration avoiding additional Aryl/Me steric strain. The Zisomer of 3 is distorted from planarity due to the strong $\mathrm{Ar} / \mathrm{Ar}-\pi$-repulsion which is in excellent agreement with the $50 \mathrm{~nm}$ blue-shift observed during $\mathrm{E} \rightarrow \mathrm{Z}$-photoisomerization (vide infra). 
<smiles>COc1ccc(C(=O)C(C)=C(c2ccccc2)c2ccccc2)cc1OC</smiles><smiles>C1=CC=C1</smiles>

(s-trans)-E-3<smiles>O=C(/C=C\C1C=CC=CC1)c1ccccc1</smiles>

(s-cis)-E-4<smiles>COc1ccc(C(=O)/C(C)=C/c2ccccc2)cc1OC</smiles><smiles>O=C(/C=C/c1ccccc1)c1ccccc1</smiles>

Scheme 3. Configurational and conformational switching of the $\alpha$-methyl chalcone 3 and the parent chalcone 4 .

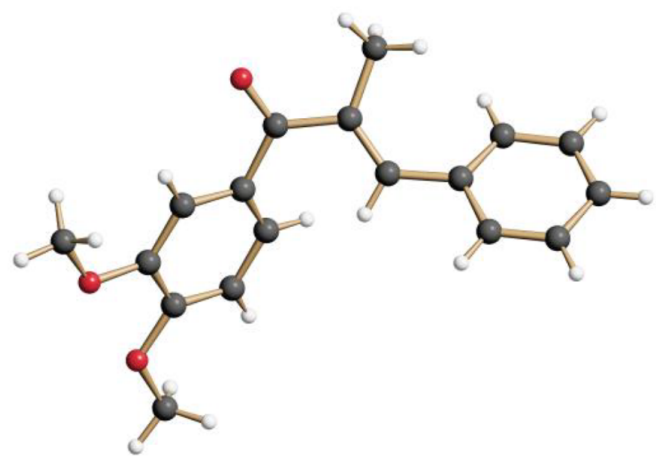

Figure 1. Structure of the $\alpha$-methyl E-chalcone 3 (s-trans configuration) in the crystal.

\subsection{E/Z-Photoswitching, PSS, and PSS-Stability of the $\alpha$-Methyl Chalcone 3}

The photochromic behavior of 3 was studied in diluted acetonitrile solutions using different excitation wavelengths. As shown in Figure 2 for $350 \mathrm{~nm}$ excitation, the UVabsorption of 3 is rapidly changing after few seconds with hypochromic shifts at 290 and $270 \mathrm{~nm}$ (negative photochromism [17]) and an isosbestic point at $258 \mathrm{~nm}$. No further changes in the absorption spectrum could be observed after $1 \mathrm{~min}$ and prolonged irradiation for several hours did not lead to further changes.

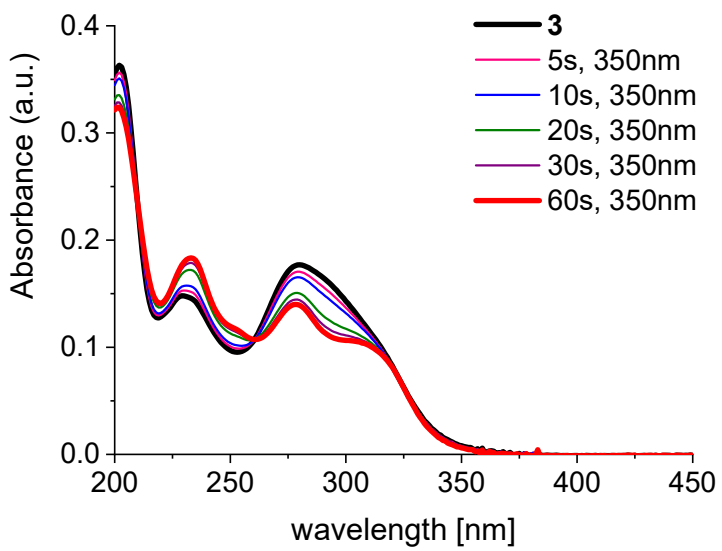

Figure 2. Irradiation at $350 \mathrm{~nm}$ of a $10^{-5} \mathrm{M}$ solution of the $\alpha$-methyl chalcone 3 in acetonitrile solutions. The photostationary equilibrium $(E / Z=35: 65)$ is reached is less than $1 \mathrm{~min}$. Negative photochromism is apparent from the bleaching of the $300 \mathrm{~nm}$ absorption and hyperchromic shift at $230 \mathrm{~nm}$. 
From the UV-absorption analyses at different excitation wavelengths and quantum yield determinations at $344 \mathrm{~nm}$, the data shown in Table 1 resulted. The PSS that were determined by NMR spectroscopy (see Figure 3) approach unity at shorter wavelength. The low PSS makes compound 3 not a useful representative of the $\alpha$-methylated chalcones which usually can be switched to PSS > 29:71, e.g., compound 5 [16] and, more important, back-switched to the initial E/Z-mixture be treatment with Broensted acids (Scheme 4, [16]). The quantum yields for forward and backward switching for compound 3 were determined by the QYD-system as developed by Riedle and coworkers [18]. The $\mathrm{Z} \rightarrow \mathrm{E}$ switch process is more efficient than the $\mathrm{E} \rightarrow Z$ switch at $344 \mathrm{~nm}$ and the PSS originates from the differences in $\varepsilon^{\lambda}$ for the E- and Z-isomers, respectively, following the relation PPS $=\left[\varepsilon^{\lambda}(E) \times \Phi^{\lambda} E \rightarrow Z / \varepsilon^{\lambda}\right.$ $\left.(\mathrm{Z}) \times \Phi^{\lambda} \mathrm{Z} \rightarrow \mathrm{E}\right]$.

Table 1. Excitation wavelength, PSS, forward-backward photoisomerization quantum yields $\Phi$.

\begin{tabular}{cccc}
\hline Excitation Wavelength $\lambda_{\text {ex }}[\mathrm{nm}]$ & PSS [E/Z Ratio, \%] & $\boldsymbol{\Phi}_{\mathrm{E}} \rightarrow_{\mathbf{Z}}{ }^{\mathbf{1}}$ & $\boldsymbol{\Phi}_{\mathbf{Z}} \rightarrow_{\mathbf{E}}{ }^{\mathbf{1}}$ \\
\hline 254 & $46: 54$ & - & - \\
300 & $40: 60$ & - & - \\
350 & $35: 65$ & 0.18 & 0.64 \\
\hline
\end{tabular}

${ }^{1}$ Quantum yields for $344 \mathrm{~nm}$ irradiation were determined by the Riedle-QYDS [17].

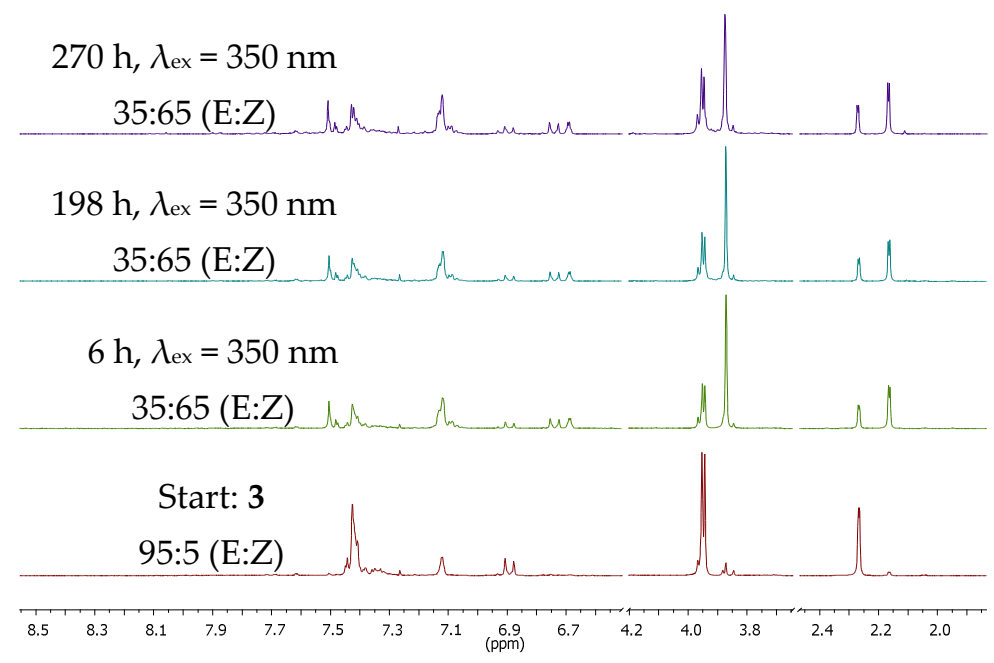

Figure 3. Long-time irradiation of the $\alpha$-methyl chalcone 3 with $350 \mathrm{~nm}$ light in acetonitrile solutions, $c=10^{-4} \mathrm{M}$. The PSS $(\mathrm{E} / \mathrm{Z}=35: 65)$ is reached after approx. $6 \mathrm{~h}$. No degradation $(<2 \%)$ is detectable even after $>11$ days of continuous irradiation.<smiles>COc1ccc(C(=O)/C(C)=C/c2ccccc2)cc1OC</smiles><smiles>[Z5]/C(=C/c1ccccc1)C(=O)c1ccc(OC)cc1</smiles>

Scheme 4. Comparison between photochromic switching and PSS at $350 \mathrm{~nm}$ and the Broensted acid back reactions of the $\alpha$-methyl chalcone 3 and its methoxy analog 5 [16]. 


\section{Materials and Methods}

${ }^{1} \mathrm{H}-\mathrm{NMR}$ spectra were recorded on a Bruker Avance 300 or on a Bruker Avance 500 spectrometer (Bruker, Ettlingen, Germany) instruments operating at $500 \mathrm{MHz}$. Chemical shifts are reported as $\delta$ in ppm and the coupling constants $J$ in $\mathrm{Hz}$ units. In all spectra, the solvent peaks were used as the internal standard. Solvents used were $\mathrm{CDCl}_{3}(\delta=7.24 \mathrm{ppm})$ and $\mathrm{MeOH}-d_{4}(\delta=3.35,4.78 \mathrm{ppm})$. Splitting patterns are designated as follows: s, singlet; $\mathrm{d}$, doublet; $\mathrm{t}$, triplet; $\mathrm{q}$, quartet; $\mathrm{m}$, multiplet; $\mathrm{br}$, broad; the ${ }^{13} \mathrm{C}-\mathrm{NMR}$ spectra were recorded either on a Bruker Avance 300 spectrometer instrument operating at $75 \mathrm{MHz}$, or on a Bruker Avance 500 spectrometer instrument operating at $125 \mathrm{MHz}$. High-resolution mass spectra (HR-MS) were recorded on a Finnigan MAT 900 spectrometer (Scientific Instrument Services, Ringoes, NJ, USA) and measured for the molecular ion peak $\left(\mathrm{M}^{+}\right)$. IR spectra were obtained on a Si crystal Fourier-Transform spectrometer by Thermo Scientific (Nicolet 380 FT-IR). Absorption spectra were recorded on a Perkin-Elmer Lambda 35. The samples were placed into quartz cells of $1 \mathrm{~cm}$ path length. All samples were measured in a concentration of $10^{-5} \mathrm{M}$ in acetonitrile.

Synthesis of (E)-1-(3,4-dimethoxyphenyl)-2-methyl-3-phenylprop-2-en-1-one (3). $1.50 \mathrm{~g}$ (7.72 mmol, 1.0 eq.) of dimethoxypropiophenone (2) and $0.83 \mathrm{~mL}$ ( $8.11 \mathrm{mmol}, 1.05$ eq.) of benzaldehyde were dissolved in a mixture of $20 \mathrm{~mL}$ of ethanol and $10 \mathrm{~mL}$ of water, treated $2.78 \mathrm{~mL}$ of a $10 \%$ aqueous $\mathrm{NaOH}$-Lösung and stirred for $5 \mathrm{~d}$ at room temperature. Extraction with methylene chloride, washing with $1 \mathrm{~N}$ aqueous $\mathrm{HCl}$, drying and solvent evaporation followed by column chromatography ( $c H$ Hex:EtOAc, 10:1) delivered the chalcone 3 in $33 \%$ yield as slightly yellow needles, m.p. $81-82{ }^{\circ} \mathrm{C} . \mathrm{C}_{18} \mathrm{H}_{18} \mathrm{O}_{3}(282.34 \mathrm{~g} / \mathrm{mol})$ $\left(300 \mathrm{MHz}, \mathrm{CDCl}_{3}\right): \delta(\mathrm{ppm})=7.47-7.41(\mathrm{~m}, 6 \mathrm{H}, \mathrm{H}-5, \mathrm{H}-6, \mathrm{H}-8, \mathrm{H}-9, \mathrm{H}-11, \mathrm{H}-15), 7.38-7.33$ $(\mathrm{m}, 1 \mathrm{H}, \mathrm{H}-7), 7.14(\mathrm{~d}, J=1.2 \mathrm{~Hz}, 1 \mathrm{H}, \mathrm{H}-3), 6.91(\mathrm{~d}, J=8.1 \mathrm{~Hz}, 1 \mathrm{H}, \mathrm{H}-14), 3.97(\mathrm{~d}, J=5.7 \mathrm{~Hz}$, $6 \mathrm{H}, \mathrm{H}-17, \mathrm{H}-18), 2.29$ (d, J = 1.4 Hz, 3H, H-16). $\left(75 \mathrm{MHz}, \mathrm{CDCl}_{3}\right): \delta(\mathrm{ppm})=198.3(\mathrm{~s}, \mathrm{C}-1)$, 152.6 (s, C-13), 148.9 (s, C-12), 139.9 (s, C-3), 136.9 (s, C-2), 135.9 (s, C-4), 130.7 (s, C-10), 129.7 (d, C-6, C-8), 128.5 (d, C-5, C-9), 128.4 (d, C-7), 124.4 (d, C-15), 112.1 (d, C-11), 109.8 $(\mathrm{d}, \mathrm{C}-14), 56.1(\mathrm{q}, \mathrm{C}-18), 56.0(\mathrm{q}, \mathrm{C}-17), 15.0(\mathrm{q}, \mathrm{C}-16) . \tilde{\mathrm{v}}\left(\mathrm{cm}^{-1}\right)=3073(\mathrm{w}), 2965(\mathrm{w}), 2934$ (w), $2902(\mathrm{w}), 2837(\mathrm{w}), 1631(\mathrm{~m}), 1594(\mathrm{~m}), 1581(\mathrm{~m}), 1510(\mathrm{~m}), 1447(\mathrm{w}), 1412(\mathrm{w}), 1356$ $(\mathrm{w}), 1302(\mathrm{w}), 1263(\mathrm{~s}), 1226(\mathrm{~m}), 1179(\mathrm{w}), 1132(\mathrm{~m}), 1022(\mathrm{~s}), 947(\mathrm{w}), 879(\mathrm{~m}), 849(\mathrm{~m})$, $766(\mathrm{~s}), 745(\mathrm{~m}), 722(\mathrm{~m}), 699(\mathrm{~m}), 657(\mathrm{w}), 598(\mathrm{w}), 527(\mathrm{w})$. Calculated mass $[\mathrm{M}-\mathrm{H}]^{+}$ $=283.1328710[\mathrm{M}-\mathrm{Na}]^{+}=305.1148156$ determined mass $(\mathrm{amu}):[\mathrm{M}-\mathrm{H}]^{+}=283.13329$ $[\mathrm{M}-\mathrm{Na}]^{+}=305.11542$.

Supplementary Materials: The following data are available online, Figures S1-S6: Chalcone 3: X-ray ellipsoid picture, ball and stick picture, ${ }^{1} \mathrm{H}-\mathrm{NMR},{ }^{13} \mathrm{C}-\mathrm{NMR}$, and IR spectra, MS analysis, Table S1: data for X-ray structure analysis [19].

Author Contributions: Conceptualization, A.G.G.; X-ray analysis and data curation, J.M.N.; writingoriginal draft preparation, B.Ö. and A.G.G.; research, B.Ö.; supervision, A.G.G. All authors have read and agreed to the published version of the manuscript.

Funding: This research received no external funding.

Institutional Review Board Statement: Not applicable.

Informed Consent Statement: Not applicable.

Data Availability Statement: Data are contained within the article or Supplementary Materials.

Conflicts of Interest: The authors declare no conflict of interest.

\section{References}

1. Bouas-Laurent, H.; Castellan, A.; Desvergne, J.P. From Anthracene Photo-Dimerization to Jaw Photochromic Materials and Photocrowns. Pure Appl. Chem. 1980, 52, 2633-2648.

2. Bouas-Laurent, H.; Dürr, H. Organic Photochromism (IUPAC Technical Report). Pure Appl. Chem. 2001, 73, 639-665.

3. Feringa, B.L.; van Delden, R.A.; Koumura, N.; Geertsema, E.M. Chiroptical Molecular Switches. Chem. Rev. 2000, 100, 1789-1816. [PubMed]

4. Hull, K.; Morstein, J.; Trauner, D. In Vivo Photopharmacology. Chem. Rev. 2018, 118, 10710-10747. [CrossRef] [PubMed] 
5. Lerch, M.M.; Hansen, M.J.; van Dam, G.M.; Szymanski, W.; Feringa, B.L. Emerging Targets in Photopharmacology. Angew. Chem. Int. Ed. 2016, 55, 10978-10999. [CrossRef] [PubMed]

6. Irie, M. Diarylethenes for Memories and Switches. Chem. Rev. 2000, 100, 1685-1716. [CrossRef] [PubMed]

7. Bleger, D.; Hecht, S. Visible-Light-Activated Molecular Switches. Angew. Chem. Int. Ed. 2015, 54, 11338-11349. [CrossRef] [PubMed]

8. Aubry, J.M.; Pierlot, C.; Rigaudy, J.; Schmidt, R. Reversible binding of oxygen to aromatic compounds. Acc. Chem. Res. 2003, 36, 668-675. [CrossRef] [PubMed]

9. Sakata, Y.; Fukushima, S.; Akine, S.; Setsune, J. Solvent-dependent dual-mode photochromism between T-and P-types in a dipyrrinone derivative. Chem. Commun. 2016, 52, 1278-1281. [CrossRef] [PubMed]

10. Kobatake, S.; Terakawa, Y. Acid-induced photochromic system switching of diarylethene derivatives between P-and T-types. Chem. Commun. 2007, 43, 1698-1700. [CrossRef] [PubMed]

11. Hadjoudis, E.; Mavridis, I.M. Photochromism and thermochromism of Schiff bases in the solid state: Structural aspects. Chem. Soc. Rev. 2004, 33, 579-588. [CrossRef] [PubMed]

12. Yun, C.; You, J.; Kim, J.; Huh, J.; Kim, E. Photochromic fluorescence switching from diarylethenes and its applications. J. Photochem. Photobiol. C 2009, 10, 111-129. [CrossRef]

13. Iwata, S.; Nishino, T.; Inoue, H.; Nagata, N.; Satomi, Y.; Nishino, W.; Shibata, S. Antitumorigenic Activities of Chalcones (II). Photo-isomerization of Chalcones and the Correlation with Their Biological Activities. Biol. Pharm. Bull. 1997, 20, 1266-1270. [CrossRef] [PubMed]

14. Ducki, S.; Forrest, R.; Ducki, S.; Forrest, R.; Hadfield, J.A.; Kendall, A.; Lawrence, N.J.; McGown, A.T.; Rennison, D. Potent Antimitotic and Cell Growth Inibitory Properties of Substituted Chalcones. Bioorg. Med. Chem. Lett. 1998, 8, 1051-1056. [CrossRef]

15. Öngel, B. Novel Photoswitches Based on Phthalimide-Based Azobenzenes and Chalcones: Synthesis and Photophysical Study of Reversible E/Z Isomerization. Ph.D. Thesis, University of Cologne, Cologne, Germany, 2020.

16. Griesbeck, A.G.; Öngel, B.; Brüllingen, E.; Renner, M. New Photochromic $\alpha$-Methylchalcones are Highly Photostable, Even under Singlet Oxygen Conditions: Breaking the $\alpha$-Methyl Michael-System Reactivity by Reversible Peroxybiradical Formation. Molecules 2021, 26, 642. [CrossRef] [PubMed]

17. Tanaka, M.; Nakamura, M.; Abdussalam Salhin, M.A.; Ikeda, T.; Kamada, K.; Ando, H.; Shibutani, Y.; Kimura, K. Synthesis and Photochromism of Spirobenzopyran Derivatives Bearing an Oxymethylcrown Ether Moiety: Metal Ion-Induced Switching between Positive and Negative Photochromisms. J. Org. Chem. 2001, 66, 1533-1537. [CrossRef] [PubMed]

18. Megerle, U.; Lechner, R.; König, B.; Riedle, E. Laboratory apparatus for the accurate, facile and rapid determination of visible light photoreaction quantum yields. Photochem. Photobiol. Sci. 2010, 9, 1400-1406. [CrossRef] [PubMed]

19. Data from Crystal Structure Analysis are Deposited at the Cambridge Crystallographic Data Centre (CCDC) with the Deposition Number CCDC 2081479. Available online: https:/ / www.ccdc.cam.ac.uk / (accessed on 2 June 2021). 